\title{
The Diagenesis of Plant Lipids during the Formation of the Krepoljin Coal Basin (Serbia) - Using Multivariate Statistical Analysis in the Saturated Biomarkers
}

\author{
Gordana DEVIĆ ${ }^{1, *}$ and Branimir JOVANČIĆEVIĆ ${ }^{1,2}$ \\ 1 Center of Chemistry, IChTM, Njegoševa 12, 11000 Belgrade, Serbia \\ 2 Faculty of Chemistry, University of Belgrade, POB 158, 11001 Belgrade, Serbia
}

\begin{abstract}
The composition of the saturated hydrocarbon fraction of soluble organic matter (bitumen) from the Krepoljin brown coal basin (East Serbia) of Miocene age was investigated. The Krepoljin basin is especially interesting from a geochemical point of view. Namely, by the end of Tertiary Period, the basin was covered by powerful Mesozoic formations of great possibilities, the bedding became hermetically enclosed and protected from subsequent external influences. The nature of early diagenetic processes in the environment with abundant accumulation of organic substance is defined by the molecular content of bitumen through the connections of molecular structures to potential precursors in paleoplant phylla, as well as by the degree of their diagenetic transformations. The hierarchy of parameters based on molecules of saturated hydrocarbons was determined by applying the principal component analysis to the soluble organic matter. The most significant, most "loadings" values of component $\mathrm{Cl}$, are the plant types such as precursors or participants in early diagenetic transformations of steranes $\mathrm{Cs}_{27}$-algal precursor material, $\mathrm{Cs}_{\mathbf{2 8}}$-moulds, $\mathrm{Cs}_{29}$-higher land and water plants; resinous from the group of higher plant gymnosperms (G); also triterpanes $\alpha$ and $\beta$-amirindicotyledonous angiosperms (A) and bacterial and/or terrestrial plants population represented by hopanes/moretanes; as well as the parameters which describe the degree of diagenetic/maturation transformation of precursor biomass, and based on next reactions: (1) shifting of methyl group, influenced by the inorganic sediment constitutents, sterane-rearranged steranes, (2) isomerization in the ring system, $\alpha \alpha \alpha \rightarrow \beta \beta \beta C_{29}$ sterane as well as (3) isomerization on chiral center of the side chain sequence $R \rightarrow S \quad C_{29}$ sterane $S /(S+R)$. Additionally, a pyrite-derived inhibitory effect on the rearrangment of $\mathbf{C}_{29}$ steranes must be taken into account, but not on triterpanes reaction. Nonappearance of statistically important correlations, before all with maturational depended parameters, and after all also with source indicators contributies to the affirmation of the newly-suggested parameter $\alpha$-Phyllocladane/ $S_{27}$ as the real source biomarker of coal. Indicators derived from the distribution and abundance of $\boldsymbol{n}$-alkanes and isoprenoid alkanes are of less significance in hierarchy of parameters.
\end{abstract}

Key words: brown coal, diagenetic transformations of saturated biomarkers, brown coal, diagenetic transformations of saturated biomarkers, steranes, diterpanes and triterpanes, principal component

\section{Introduction}

Organic geochemical research of coals allows for establishment of the connection between the organic components of biosphere: biolipids and biopolymers as well as the organic components of geosphere: geolipids and geopolymers.

Distribution of biomarkers in low-rank coals has attracted special attention in the past decades. These studies document the distribution of diagenetic changes which occur on molecular level during the transformation of paleoflora and formation of coals and identification of

* Corresponding author. E-mail: gordana.devic@yahoo.com many classes of organic compound, primarily molecular fossils (Wang and Simoneit, 1990; Sajgo et al., 1992; Stout, 1992; Dehmer, 1995, 1988, 1989; Stefanova et al., 1995, 1999, 2005; Kalkreuth et al., 1998; Sun et al., 1998; Papanicolaou et al., 2000; Gruber and Sachsenhofer, 2001; Bechtel et al., 2001, 2002, 2003, 2005; Hetényi et al., 2002; Tuo et al., 2003; Oritz et al., 2004; Tuo and Philp, 2005).

Some transformations are under the influence of availability of oxygen, local conditions of $\mathrm{pH}$, mineral matrix, and microbiological activities. We can find the evidence of microorganisms occurring by way of the presence of molecular moieties as the hopanes. Also, it is possible to distinguish inputs of certain paleo-plant 
community: diterpenoids from gymnosperms and specific triterpenoids of amirin ( $\alpha$ - and $\beta$-) types, from dicotyledonous angiosperms.

As of the 1990s special attention has been paid to the identification of key intermediates, $\Delta^{2}$-triterpanes ( $\alpha$ - and $\beta$ -amirin), which brings one closer to the full understanding of diagenetic fate of terrigenous (angiosperms) triterpenoids (Wang and Simoneit, 1990; Stout, 1992; ten Haven et al., 1992; Stefanova et al., 1995, 1999; Kalkreuth et al., 1998; Bechtel et al., 2001).

The degree of these diagenetic transformations can usually be determined based on the parameters calculated from the distribution of abundance of saturated hydrocarbons, although their application can be limited. Variations in some parameters are clearly dominated by maturity, others are dominated by source input (including organic matter input and depositional environment), and some depended by inorganic minerals of source rocks (Peters and Moldowan, 1993). One of the main challenges in molecular organic geochemistry is the identification of biological source of organic substances of sediment formations which should point to the biological specificity and which should strictly define the source indicatory potential. We created an assignment to search for the source indicatory molecule which would unambiguously be connected to a specific plant phylla and with that we tried to characterize paleoecosystem of the Krepoljin basin.

The characterization of this basin is of special fundamental significance, because we are talking about the brown coal bedding, which due to later tectonic shifting became hermetically enclosed and has been protected from the exterior influences (Maksimović and Bokčić, 1975; Devic et al., 2006). Organic-geochemical research includes the reconstruction of plant association of the precursor biomass based on the set of biomarkers of the aliphatic fraction of organic substances and earlier research correlation of the mentioned association with paleoecological conditions: the intensity of sulfatereduction environment in geological sequence (Devic et al., 2006), not only on the base of literately well known source indicators and diagenetic-maturation parameters. The interest was in the definition of the novel sources parameter (ratios) which would as well as possible separate and clarify plant associations in paleo-ecosystem of coal of the Krepoljin basin by applying multivariate statistic principal component analysis also with prediction of the order of the influence of precursor groupings and the order of development of isomerization process in molecules of cyclic hydrocarbons.

Principal component analysis: Principal Component Analysis (PCA) has become in our days an important statistical instrument of investigation in modern science, being an adequate tool to investigate the principles of interaction of components and their integration into a system. It is an exploratory multivariate statistical method that can be used to identify relations in large data sets influenced by multiple variables. Principal Components, PCs, are derived through PCA and represent a linear combination of original variables that account for the largest possible portion of the original total variance. Also, PCA gives an option with the varimax rotation application as stricter criteria in statistical parameter classification, so that a great number of parameters join in a significantly smaller number of components. The value of the coefficient in front of the parameter ("loadings") defines the significance of the specific parameter of the observed group of samples (Dahl et al., 1993; Kumar et al., 2001; Kaplunovsky, 2004). In this way we tried to estimate the establishment of the observed parameter of saturated hydrocarbon and also the order of reaction development of epimerization of sterane and terpane molecules.

Principal component analysis using the parameters is shown in Table 1. With the application of principal component analysis (SPS S 10.0 for Windows); it was established that the coal with more than $92.03 \%$ of variance in biomarker ratios can be explained with 4 components (Table 2).

\section{Samples}

All the samples studied here include the brown coal samples from two explored boreholes, J-98 and J-99. Hence, the sample descriptions and their geological background are found in the previous paper (Devic et al., 2006).

\section{Experimental Part}

Total organic matter: The ground samples ( -80 mesh) were treated with $\mathrm{HCl}(1: 1 \mathrm{v} / \mathrm{v})$ and then with $\mathrm{HCl}-\mathrm{HF}$ mixture (1:1 v/v) and after that again with $\mathrm{HCl}(1: 1 \mathrm{v} / \mathrm{v})$. The residues were filtered and then dried at $105^{\circ} \mathrm{C}$. The pyrite content was determined from $\mathrm{Fe}_{2} \mathrm{O}_{3}$ after the ignition of the $\mathrm{HCl}-\mathrm{HF}$-treated samples. The content of $\mathrm{OM}$ was calculated by difference. The elemental compositions of organic matter $\mathrm{C}, \mathrm{H}, \mathrm{O}, \mathrm{N}$ and $\mathrm{S}$ were determined by microanalysis of the $\mathrm{HCl}$-HF-treated samples (oxygen was calculated by the difference to $100 \%$ ).

Soluble organic matter: The extraction of powdered coal samples was carried in a Soxhlet apparatus with dichloromethane ( $36 \mathrm{~h})$. After the extraction, the greater part of the solvent was removed using a rotating vacuum evaporator.

The saturated hydrocarbons were isolated on a column 

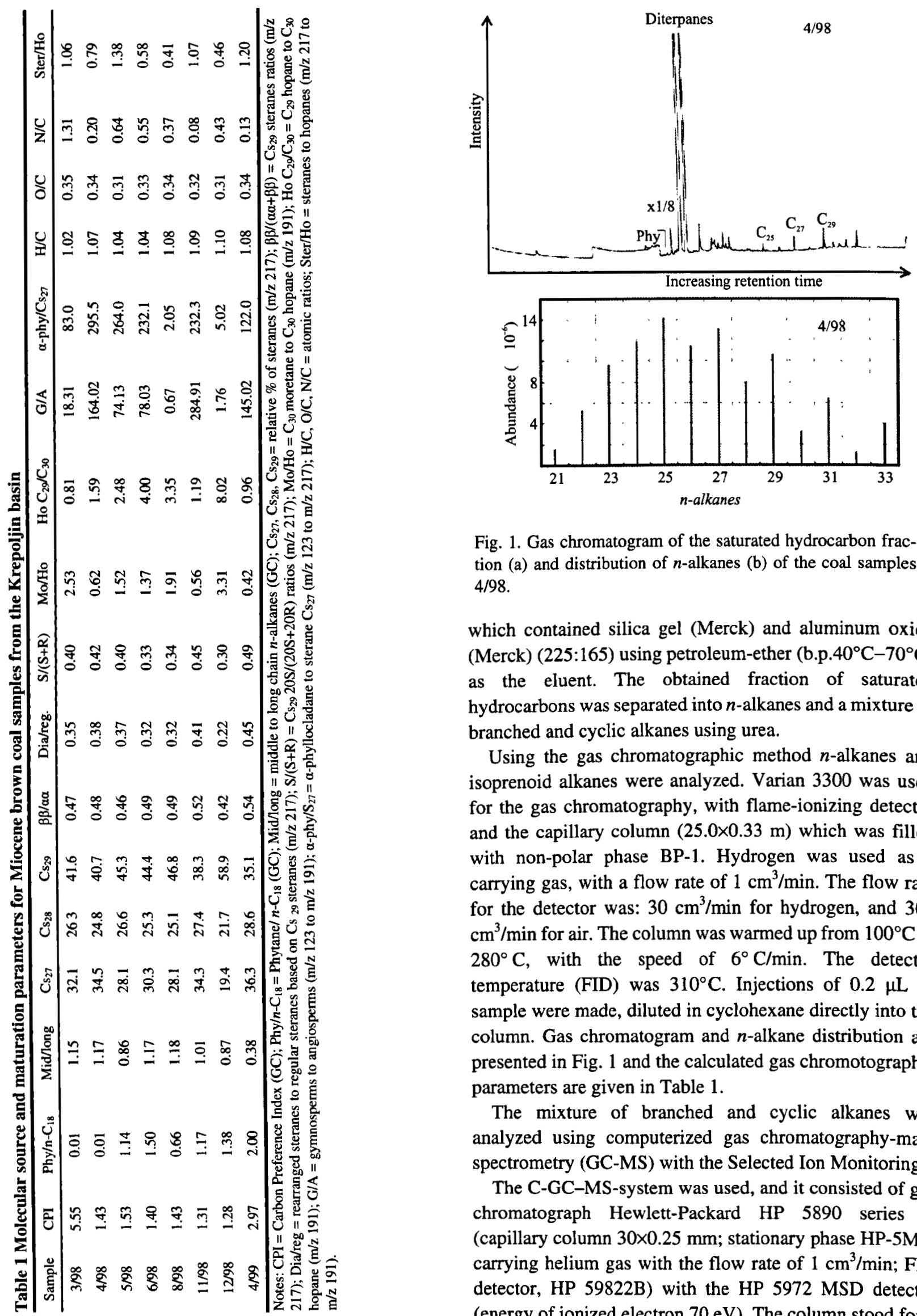

Fig. 1. Gas chromatogram of the saturated hydrocarbon fraction (a) and distribution of $n$-alkanes (b) of the coal samples $4 / 98$.

which contained silica gel (Merck) and aluminum oxide (Merck) (225:165) using petroleum-ether (b.p. $40^{\circ} \mathrm{C}-70^{\circ} \mathrm{C}$ ) as the eluent. The obtained fraction of saturated hydrocarbons was separated into $n$-alkanes and a mixture of branched and cyclic alkanes using urea.

Using the gas chromatographic method $n$-alkanes and isoprenoid alkanes were analyzed. Varian 3300 was used for the gas chromatography, with flame-ionizing detector and the capillary column $(25.0 \times 0.33 \mathrm{~m})$ which was filled with non-polar phase BP-1. Hydrogen was used as a carrying gas, with a flow rate of $1 \mathrm{~cm}^{3} / \mathrm{min}$. The flow rate for the detector was: $30 \mathrm{~cm}^{3} / \mathrm{min}$ for hydrogen, and 300 $\mathrm{cm}^{3} / \mathrm{min}$ for air. The column was warmed up from $100^{\circ} \mathrm{C}$ to $280^{\circ} \mathrm{C}$, with the speed of $6^{\circ} \mathrm{C} / \mathrm{min}$. The detector temperature (FID) was $310^{\circ} \mathrm{C}$. Injections of $0.2 \mu \mathrm{L}$ of sample were made, diluted in cyclohexane directly into the column. Gas chromatogram and $n$-alkane distribution are presented in Fig. 1 and the calculated gas chromotographic parameters are given in Table 1.

The mixture of branched and cyclic alkanes was analyzed using computerized gas chromatography-mass spectrometry (GC-MS) with the Selected Ion Monitoring.

The C-GC-MS-system was used, and it consisted of gas chromatograph Hewlett-Packard HP 5890 series II (capillary column $30 \times 0.25 \mathrm{~mm}$; stationary phase HP-5MS; carrying helium gas with the flow rate of $1 \mathrm{~cm}^{3} / \mathrm{min}$; FID detector, HP 59822B) with the HP 5972 MSD detector (energy of ionized electron $70 \mathrm{eV}$ ). The column stood for 3 
Table 2 Principal component analysis for coal

\begin{tabular}{|c|c|c|c|c|c|}
\hline \multicolumn{2}{|c|}{$\begin{array}{c}\text { Component } 1 \\
48.261 \%\end{array}$} & \multicolumn{2}{|c|}{$\begin{array}{c}\text { Component } 2 \\
15.874 \% \\
\end{array}$} & $\begin{array}{c}\text { Component } 3 \\
15.332 \% \\
\end{array}$ & \multirow{2}{*}{$\begin{array}{c}\text { Component } 4 \\
12.686 \%\end{array}$} \\
\hline$\overline{\mathrm{Cs}_{27}}$ & +0.971 & $\alpha \mathrm{Phyll}^{2} / \mathrm{Cs}_{27}$ & +0.741 & $\mathrm{Ph} / n-\mathrm{C}_{18}+0.869$ & \\
\hline $\mathrm{Cs}_{28}$ & +0.873 & CPI & -0.725 & Mid/long -0.902 & $\mathrm{H} / \mathrm{C}-0.818$ \\
\hline $\mathrm{Cs}_{29}$ & -0.977 & $\mathrm{~N} / \mathrm{C}$ & +0.839 & & \\
\hline Dia/reg & +0.957 & & & & \\
\hline $\mathbf{S} /(\mathbf{S}+\mathbf{R})$ & +0.896 & & & & \\
\hline \multicolumn{6}{|c|}{$\beta \beta /(\alpha \alpha+\beta \beta)+0.932$} \\
\hline & +0.721 & & & & \\
\hline \multicolumn{3}{|c|}{$\mathrm{C}_{29} \mathrm{Ho} / \mathrm{C}_{30}-0.886$} & & & \\
\hline $\mathrm{Mo} / \mathrm{HoC}$ & -0.889 & & & & \\
\hline
\end{tabular}

Table 3 Identification of the peaks of the TIC, $\mathrm{m} / \mathrm{z} \mathrm{123,} 191$ and 217 mass fragmentograms

\begin{tabular}{|c|c|}
\hline No. Compound & $\mathrm{m} / \mathrm{z}$ \\
\hline $\begin{array}{l}1 \text { Norpimaran, } \mathrm{C}_{19} \mathrm{H}_{34} \\
2 \text { Sandarocopimarane, } \mathrm{C}_{20} \mathrm{H}_{36} \\
3 \mathrm{a} \mathrm{C}_{20} \mathrm{H}_{36} \text { unknown diterpane } \\
3 \text { 16( } \alpha) \mathrm{H} \text {-Phyllocladane, } \mathrm{C}_{20} \mathrm{H}_{34} \\
\text { S Simonellite, } \mathrm{C}_{19} \mathrm{H}_{24} \\
\mathrm{R} \text { Retene, } \mathrm{C}_{18} \mathrm{H}_{18} \\
\end{array}$ & $\begin{array}{c}\text { TIC } \\
\text { and } m / z \quad 123\end{array}$ \\
\hline 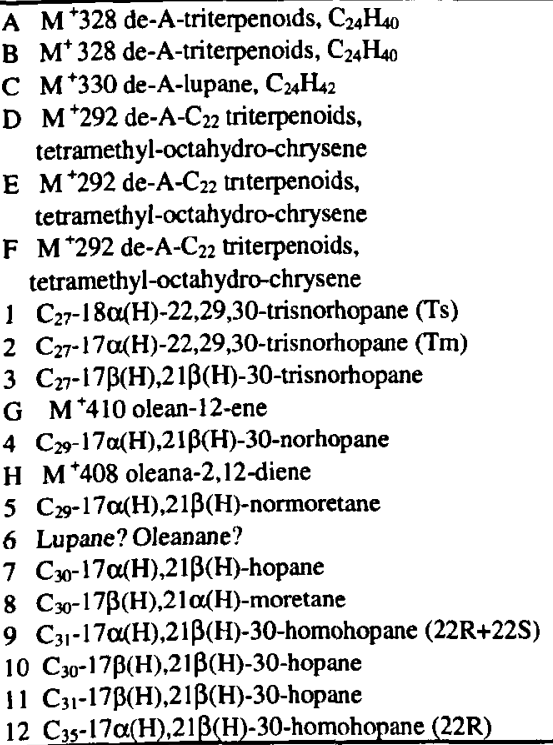 & $\mathrm{m} / \mathrm{z} 191$ \\
\hline 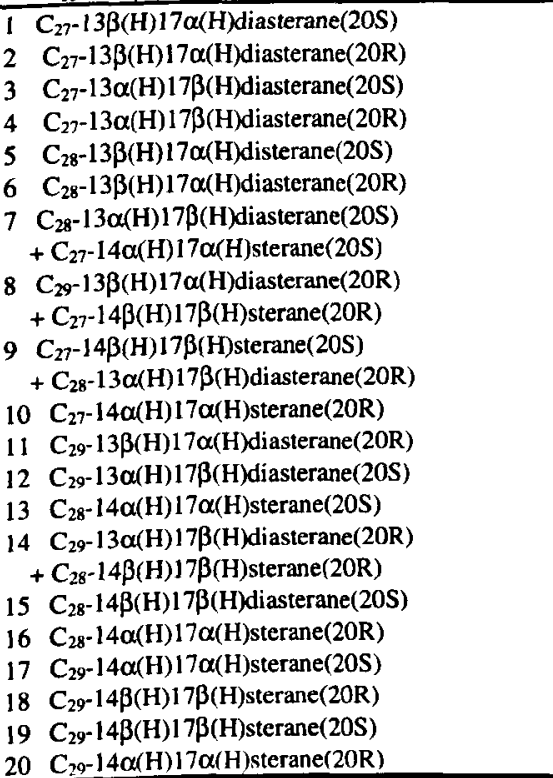 & $\mathrm{m} / \mathrm{z} 217$ \\
\hline
\end{tabular}

min at $40^{\circ} \mathrm{C}$, heated with the rate of $15^{\circ} \mathrm{C} / \mathrm{min}$ to $160^{\circ} \mathrm{C}$, and then with the speed of $20^{\circ} \mathrm{C} / \mathrm{min}$ in the temperature interval of $160^{\circ} \mathrm{C}-300^{\circ} \mathrm{C}$. The $0.1 \mu \mathrm{L}$ of sample diluted in cyclohexane was injected directly into the column, using the autosampler.

The peaks were identified by comparing fragmentograms with the literature data, and/or on the basis of total mass spectra (Noble et al., 1985, 1986; Philp, 1985; Stout, 1992; Stefanova et al., 1995, 1999).

The specific source and maturation parameters were calculated from the distribution and the abundance of biomarkers saturated factions is shown in Table 1. GCMS fragmentograms $\mathrm{m} / \mathrm{z} 123, \mathrm{~m} / \mathrm{z} 191$ and $\mathrm{m} / \mathrm{z} 217$, typical for the Krepoljin brown coal are presented in Fig. 2 , and identification of all the above data is in Table 3 .

\section{Results and Discussion}

Component 1 (47. $67 \%$ of variance) is made of biomarker parameters, Tables 1 and 2, which point to: (1) plant types as precursors or participants in early diagenetic transformations: steranes $\mathrm{Cs}_{27}$-algal biomass, $\mathrm{Cs}_{28}$-mould, $\mathrm{Cs}_{29}$-higher land and water plants; resinous from the group of higher plants gymnosperms $(G)$; then triterpanes of $\alpha$ - and $\beta$-amirin type dicotyledonous angiosperms (A) and bacterial population represented by participation of hopanes; (2) parameters describing the degree of diagenetic-maturation transformation of precursor biomass formed by the following reactions: (a) isomerization on chiral center of the side chains sequence $\mathrm{R}-\mathrm{S} \mathrm{Cs}_{29}$ steranes $\mathrm{S} /(\mathrm{S}+\mathrm{R})$, (b) isomerization in the ring system, $\alpha \alpha>\beta \beta \mathrm{Cs}_{29}$ steranes as well as terpanes $\beta \alpha \mathrm{Mo}-\alpha \beta \mathrm{Ho}$, (c) shifting of methyl-group, influenced by the inorganic sediment constituents, regular steranes-rearranged steranes (diasteranes).

Component 1 assembles all sterane parameters. Opposite signs of loadings $\mathrm{Cs}_{29}$ and $\mathrm{Cs}_{27} / \mathrm{Cs}_{28}$ are a result of complementary participation of higher terrestrial plants, and algal/mould biomass. Positive correlation $\mathrm{Cs}_{28}$ mould indicator and $\mathrm{Cs}_{27}$ sterane, indicator of algal biomass (Dević et al., in press) ( $r=0.833 ; p=0.0103$; $n=8$ ) points to predominant mould association with the environment in which developed. Within higher terrestrial plants it is possible to make detailed group separations in gymnosperms and dicotyledonous angiosperms. Tr- and tetra-cyclic diterpanes (Fig. 2 and Table 3) are used for indication of resinous higher plants, gymnosperms in the starting biomass, and for angiosperms indicators are used triterpanes $\alpha$ - and $\beta$ amirin types (Fig. 2, Table 3). The ratio of abundance of gymnosperms and angiosperms (G/A) is very different and it ranges from 0.67-284.91 (Table 1) and no 

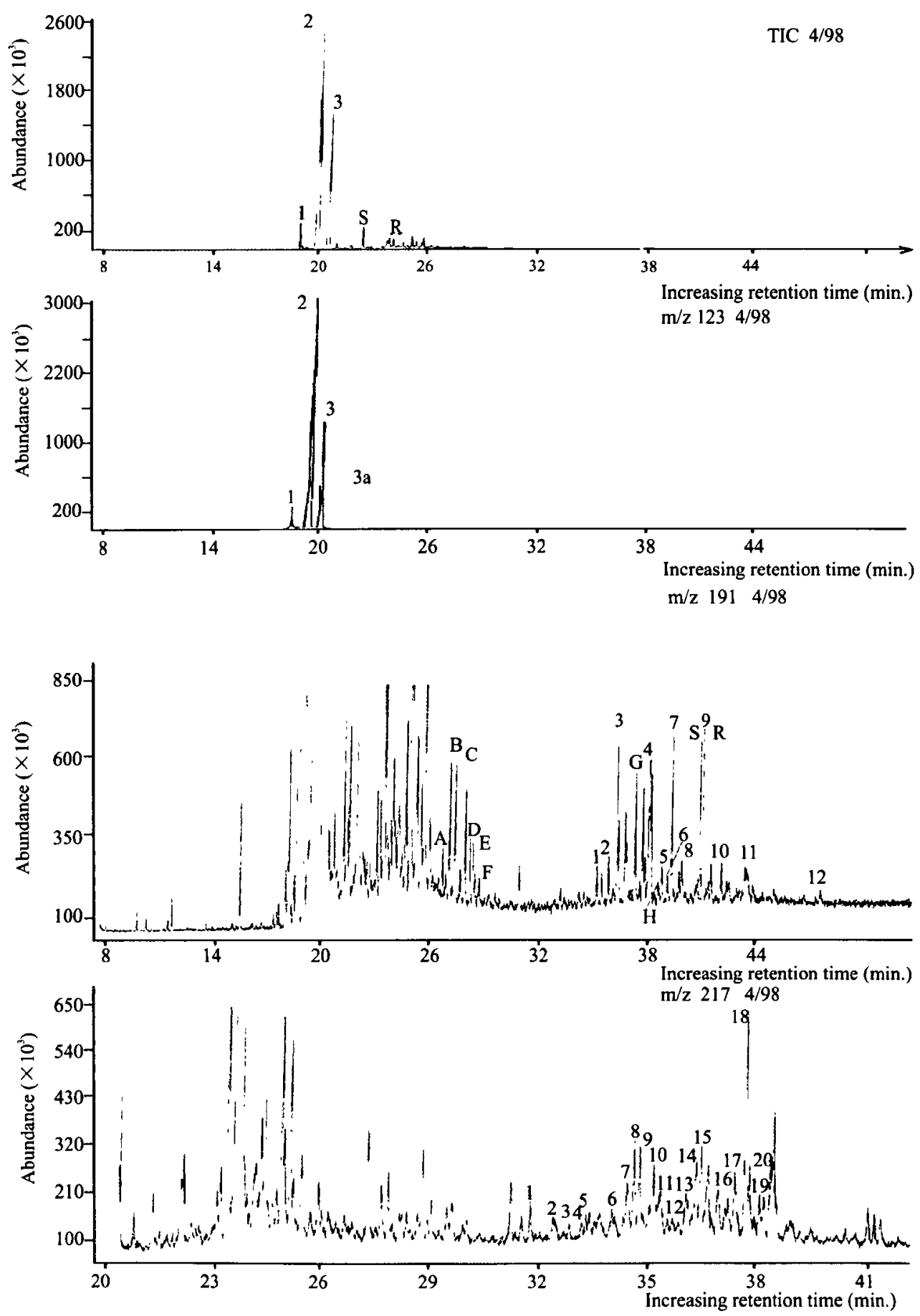

Fig. 2. TIC and mass fragmentograms $\mathrm{m} / \mathrm{z} 123, \mathrm{~m} / \mathrm{z} 191$ and $\mathrm{m} / \mathrm{z} 217$ of the saturated hydrocarbon fraction of coal sample 4/98.

correlation was found between $\mathrm{G} / \mathrm{A}$ and the depth.

Detailed determination of precursor types association shows a correlation of ratio with relative representation of gymnosperms and angiosperms (G/A) with steranes indicators: (a) insignificant correlation of inverse proportionality ( $r=-0.661 ; p=0.075, n=8$ ) shows that the increase of plant precursor material of $\mathrm{Cs}_{29}$ steranes in swamps where they formed coal, proportionally to the growth of participation of angiosperms, (b) with the determination of connection of precursor biomass of G/A with the water environment whose indicator is $\mathrm{Cs}_{27}$ steranes an absence of association of angiosperms with algal biomass, i.e. sedimentary aquatic environment $(r=0.630$; $p=0.068 ; n=8$ ) was noticed.

The weakest correlation of direct proportionality was obtained with $\mathrm{Cs}_{28}$ steranes ( $r=0.500 ; p=0.160 ; n=8$ ) pointing to the moulds as significant participants in decomposition of the starting biomass, and together with algae they were closely connected with higher plants of the gymnosperm group. On the other hand, absence of 

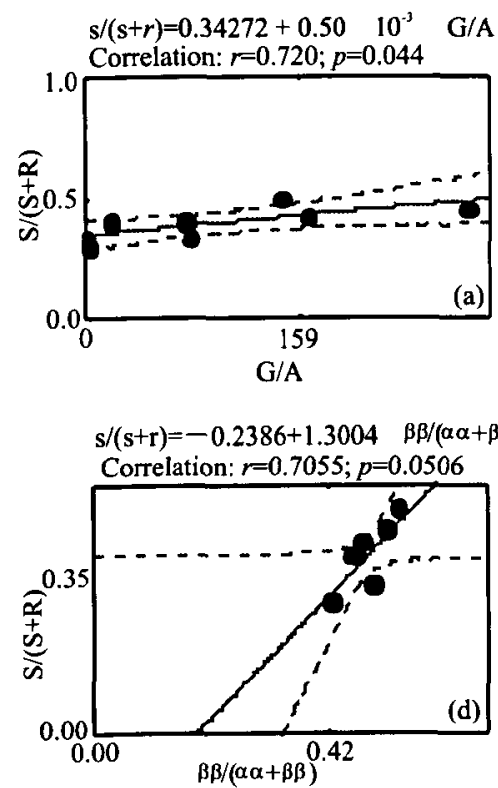

$\mathrm{Dia}=-0.3681+1.4903 \quad \beta \beta /(\alpha \alpha+\beta \beta)$ Correlation: $r=0.800 ; p=0.017$
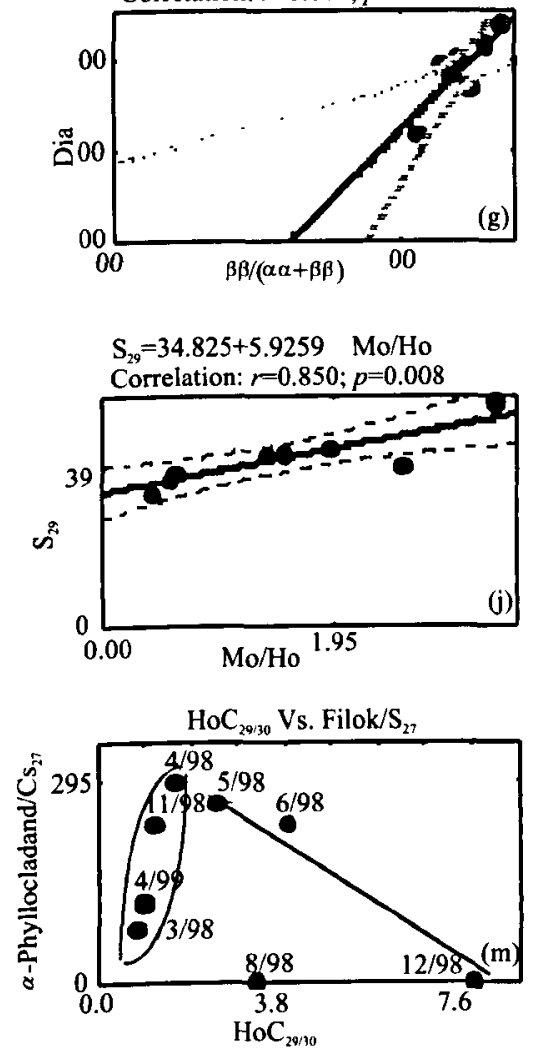

compatibility of angiosperms with algal contribution steranes $\mathrm{Cs}_{27}$ with $\mathrm{Cs}_{28}$ mould steranes in Krepoljin coal samples shows that angiosperms as precursor material were predominantly of allochthonous origin, in respect to the freshwater swamp.

The fact that G/A ratios in coal are significantly correlated only with parameters $S /(S+R), \beta \beta /(\alpha \alpha+\beta \beta)$, $\mathrm{dia} / \mathrm{reg}$ steranes (Fig. 3) shows that the introduction of higher plants in the environment where coals formed was
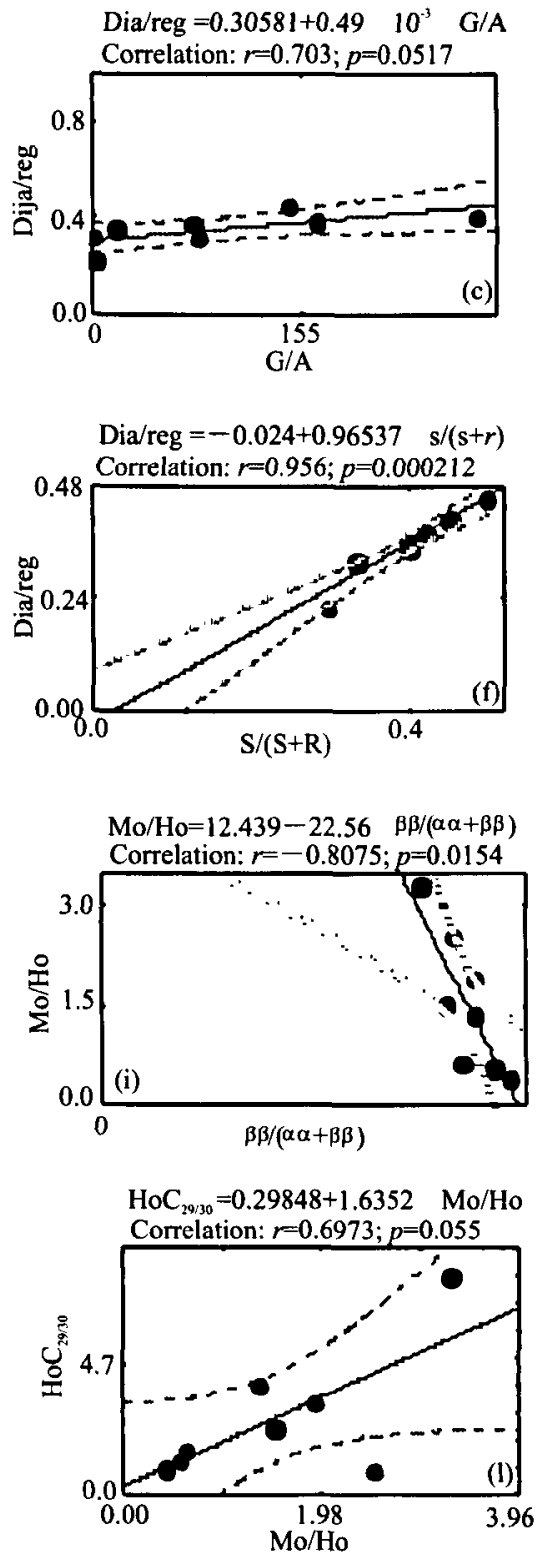

Fig. 3. Correlation diagrams: (a) G/A vs. $S /(S+R)$; (b) G/A vs. $\beta \beta /(\alpha \alpha+\beta \beta)$; (c) G/A vs. Dia/reg; (d) $\beta \beta /(\alpha \alpha+\beta \beta)$ vs. $S /(S+R)$; (e) $S /(S+R)$ vs. Spyr $(\mu M / L)$; (f) $\mathrm{S} /(\mathrm{S}+\mathrm{R})$ vs. Dia/reg; (g) Dia/reg vs. $\beta \beta /(\alpha \alpha+\beta \beta)$; (h) Dia/reg vs. Spyr $(\mu \mathrm{M} / \mathrm{L})$; (i) $\beta \beta /(\alpha \alpha+\beta \beta)$ vs. Mo/Ho; (j) Mo/Ho vs. $\mathrm{Cs}_{29}(\%)$; (k) Ho $\mathrm{C}_{29} / \mathrm{C}_{30}$ vs. $\mathrm{Cs}_{29}(\%)$; (l) $\mathrm{Mo} / \mathrm{Ho}$ vs. $\mathrm{HoC}_{29} / \mathrm{C}_{30}$; (m) $\mathrm{Ho} \mathrm{C}_{29} / \mathrm{C}_{30}$ vs. $\alpha$-Phyllocladane/Cs 27 .

connected with diagenetic steranes transformations.

No correlation was found between ratio G/A and the following parameters:

CPI $(r=-0.188 ; p=0.720, n=8)$, lower/higher $n$-alkane $(r=-0.013 ; p=0.098, n=8)$, Phy $/ n C-18(r=+0.140 ; p=0.837$; $n=8)$, and atomic N/C $(r=+0.394 ; p=0.328, n=8), \mathrm{H} / \mathrm{C}$ $(r=+0.290 ; p=0.493, n=8)$ and $\mathrm{O} / \mathrm{C}(r=-0.087 ; p=0.837$; $n=8$ ) ratios.

Maturation parameters are mainly based on chemical 
transformations of saturated hydrocarbons in the soluble organic matter of the sediment. Due to the fact that the maturation transformations of sedimentary organic matter are influenced by several different factors: (a) greatly influenced by sources input, (b) environment conditions, and (c) even the fact that the rock minerals do not have the same catalytic influence on all reactions that lead to structural and stereochemical changes on molecules, and therefore have lost their potential as a maturity indicator and/or which limits their usage (Jovancićević et al.,1992; Peters and Moldowan, 1993). Main reactions of sterane isomerization occur in the ring system and at the side chains sequence. The existence of statistically significant correlation, but not highly significant among sterane maturation parameters of $\mathrm{Cs}_{29}$ steranes $\beta \beta /(\beta \beta+\alpha \alpha)$ and $\mathrm{S} /$ $(S+R)$, is of different sequential nature of equilibrium chiral centers of the side chain sequence R-S and in the ring system $\alpha \alpha-\beta \beta$, and/or partially inhibitory effect of pyrite sulfur (Fig. 3) on isomerization R-S of side sequence, which was occurring during the formation of coals.

These two sterane parameters evidently show insufficient thermal changes, Table 1.

Both sterane maturation parameters, $\beta \beta /(\alpha \alpha+\beta \beta)$ and $S$ $(S+R)$, are significantly correlated with the parameters involved by component $\mathrm{C} 1$.

Methyl group shifting from the position $\mathrm{C}_{10}$ and $\mathrm{C}_{13}$ on $\mathrm{C}_{5}$ and $\mathrm{C}_{4}$ steranes into rearranged steranes during carbonification can be crucially influenced by catalytic activities of clay minerals. Catalysis by acidic sites on clays has been proposed as the mechanism by which diasteranes are produced in sediments. Dia/sterane ratios are affected by both thermal maturity and inorganic characteristics of the source rock. However, it is shown that the immature sediments of predominantly carbonate type contain high quantity of diasteranes, which points to some other mechanisms of existence of these geoisomers (Moldowan et al., 1992). In samples with similar origin and sediment environment, such as samples of coal at the Krepoljin basin, the ratio $\mathrm{dia} /(\mathrm{dia}+\mathrm{reg})$ steranes is a more diagenetic transformation parameter (Fig. $3 f$ and g). Also, the influence of pyrite sulfur on sterane diastereoisomerization, which is present during the transformation in between $R$ and $\mathbf{S}$ isomer steranes, is emphasized (Fig. 3h).

Unlike steranes precursor, which originates from steroids present in eukaryote, terpanes precursors are biolipid procaryotic organisms, bacteria. The remainder of organic substance of microorganisms which participated in the decomposition of burial flora incorporated in the organic matter and in that way it became a part of precursor biomass. This is reported by identified: $\alpha \beta$ hopanes and $\beta \alpha$ moretanes, $\beta \beta$ hopanes, neohopenes, isomers $\mathrm{Tm}$ and Ts and incomplete series of homohopanes (Fig. 2, Table 3).
Due to the appearance of coeluting unidentified triterpane with $C_{31}$ hopanes (in most coal samples), the use of isomerization parameter on C-22 atom R-S is missing.

The other maturation parameter is related to the irreversible isomerization of $\mathrm{C}_{30}$ moretane into the thermodynamically more stable $C_{30}$ hopane. The intensity of transformation of moretane into hopane, similarly with sterane isomerizations, is significantly influenced by geological time (pre-Tertiary age). The same component C1 contains a sterane $\mathrm{Cs}_{29} \beta \beta /(\alpha \alpha+\beta \beta)$ and terpane maturation parameters $\mathrm{C}_{30} \mathrm{Mo} / \mathrm{Ho}$ (Fig. 3i), and naturally, being that these parameters assume isomerization in the ring system and these indicators of maturation represent a stricter criterium compared to those which describe isomerization at side chain sequence. Sterane parameters are more reliable indicators of the thermal transformation process than terpane parameters (Peters and Moldowan, 1993).

In fact, it is shown (Rullkötter et al., 1984, 1994) that certain terrestrial plant biota contain moretane so the influence of precursor material on the value $\mathrm{Mo} / \mathrm{Ho}$ is reflected on the existence of correlation with the indicator of higher terrestrial plants, $\mathrm{Cs}_{29}$ sterane (Fig. 3j).

Ratio $\mathrm{C}_{29} \mathrm{Ho} / \mathrm{C}_{30}$ is sensitive to lithological changes; however $\mathrm{C}_{29}$ hopane just like moretane, labels precursor biomass (Philp, 1985; Ramanampisoa et al., 1990; Fig. 3k and 1$)$. The $\mathrm{C}_{29} \mathrm{Ho} / \mathrm{C}_{30}$ ratio can be statistically negative correlated sterane maturation indicators: dia/reg, $S /(S+R)$, $\beta \beta /(\alpha \alpha+\beta \beta)$ (not shown); which stresses the significance of terrestrial plant biota accumulating. Therefore, the transformations of biomarkers $\mathrm{Mo} / \mathrm{Ho}$ and $\mathrm{C}_{29} \mathrm{Ho} / \mathrm{C}_{30}$ are under the strong source material influence, losing their potential as a maturity indicator in these brown coals.

Correlation diagram $\mathrm{C}_{29} \mathrm{Ho} / \mathrm{C}_{30}$ with a new proposed parameter $\alpha$-Phyllocladane/Cs 27 (Fig. $3 \mathrm{~m}$ ) is an interesting example of negative correlation for all samples, but in the diagram the sequences of the sample are grouped into two subpopulations. The first group (including four samples 3 , $4,11 / 98$ and $4 / 99$ ) forms a statistical significant regression line $(r=+0.972 ; p=0.0281)$, indicating again fresh water participation of gymnosperms in the transport of precursor material and its accumulation processes. For other four samples a significant role of fresh water originating material is not indicated.

Sterane and terpane maturation parameters are within the range which agrees with the values of lower carbonification (brown coal stage) (Table 1).

Besides this, weaker correlations of maturation parameters can be explained by the influence of precursor materials, but not all reactions of the aliphatic molecules have to occur simultaneously every time, probably as a result of different catalytic effects of the associated mineral 

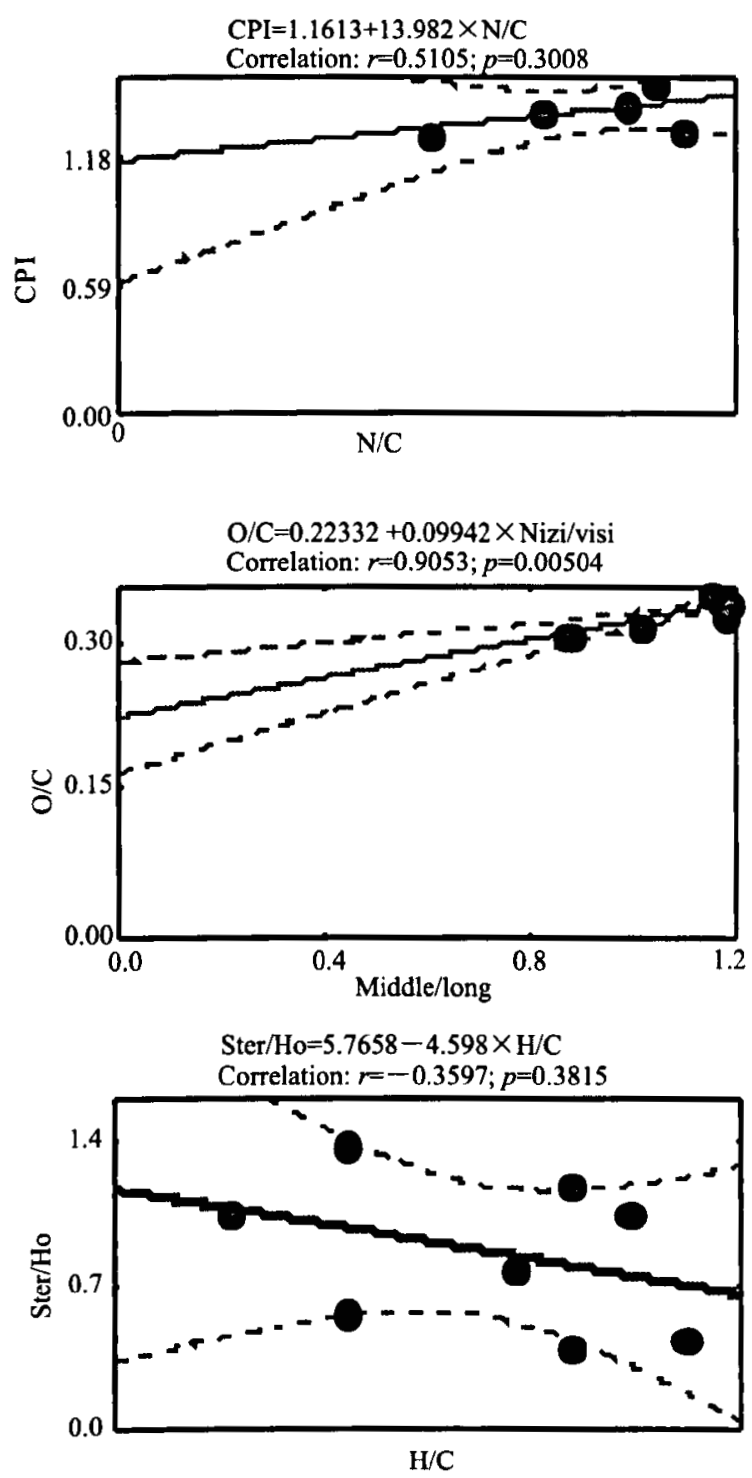

components, i.e. strong organic-inorganic interactions have occurred during the brown coal genesis.

Component $2(15.97 \%$ of variance) makes $\alpha$ Phyllocladane $/ \mathrm{Cs}_{27}+0.741$; $\mathrm{CPI}-0.728$; and atomic ratio $\mathrm{N} / \mathrm{C}+0.838$

One of the main challenges in molecular organic geochemistry is identification of the biological source of the organic input to sediment formations, which is complicated by the lack of biological specificity of most compounds. Thus, the organic geochemist seeks molecules which can be unambiguously linked to a specific family/ species and come to the idea that the compounds which belong to the tetracyclic diterpane class are the best candidate for completion of the assignment.

Due to insufficient selectivity and/or sensitivity and even uselessness of some maturation parameters saturated with hydrocarbons, we tried to introduce a new parameter ratio $\alpha$ -Plyllocladane/Cs $\mathrm{Cs}_{27}$ as a reliable source marker of specific plant groupings: $\alpha$-Phyllocladane reflects the gymnosperm
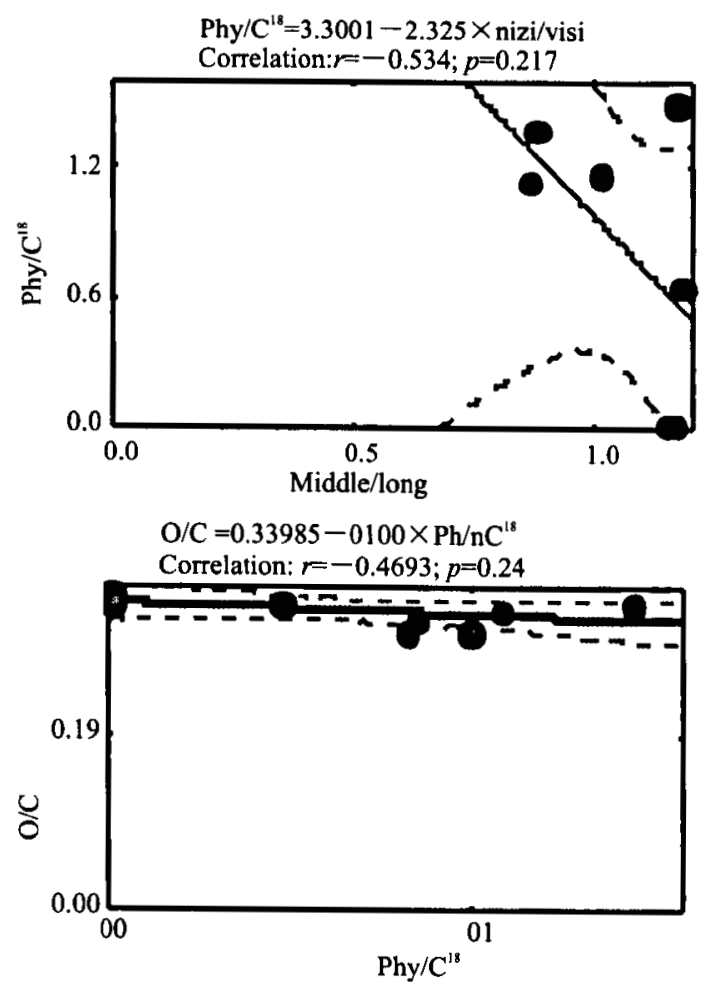

Fig. 4. Correlation diagrams: (a) N/C vs. CPI; (b) Mid./long vs. Phy $/ n-\mathrm{C}_{18}$; (c) Mid./long vs. $\mathrm{O} / \mathrm{C}$; (d) Phy/n-C 18 vs. O/C; (e) H/C vs. Ster/Ho.

input of selected types (Karrer, 1958; Erdtman and Norin, 1966; Karrer et al., 1977; Noble et al., 1985; Dehmer, 1989, 1995; Sukh, 1989; Brukner-Wein and Sajgo, 1991; Disnar and Harouna, 1994), while sterane $\mathrm{Cs}_{27}$ reflects algal biomass (Fu et al., 1986; Volkman, 1988, 1999; Jørgensen et al., 1990; Sirce et al., 1993) to define the paleoecosystem of coal in the Krepoljin basin based on their abundance. We used a multivariate principal component analysis to clear the assignment. We correlated the newly-suggested source indicator with the other source and maturation indicators in that order.

No correlation was found between source parameter $\alpha$ Phyllocladane/ $\mathrm{Cs}_{27}$ and the indicator of diagenesis/ maturation transformations, while it shows a slightly marked positive correlation trend with alkane parameter ( $r=0.420 ; p=0.408 ; n=6$ ), except extremely high values of the CPI sample $3 / 98$ and 4/99. It shows negative and no significant correlations with source parameter $\mathrm{Cs}_{29}$ steranes, and also with the parameters which are defined as 
possible source parameters and are classified in $\mathrm{C1}(\mathrm{Mo} / \mathrm{Ho}$ and $\mathrm{C}_{29} \mathrm{Ho} / \mathrm{C}_{30}$ ), pointing to a heterogenous (allochthonous) precursor biomass which participated in the coal-forming environment.

The other parameter involved by component $\mathrm{C} 2$ is the alkane parameter CPI, with the value ranging from 1.28 2.97 with the exception of the sample $3 / 98$ which contains significantly a higher CPI value of 5.55 .

CPI values are reduced in the investigated samples in comparison with coals of similar ranks (Stefanova et al., 1995; Papanicolaou et al., 2000, Bechtel et al., 2001). CPI values which are relatively low, are most likely the result of participation of hydrocarbons of different origins (higher land plants, bacterial metabolites), and/or a result of specific diagenesis which occurred in a relatively closed system. Being that we are talking about sediments in which the maturation processes have not been expressed, maturation on this sediment cannot be the reason for lower CPI values, or the lower maximum $n$-alkane. Only one statistical but not significant correlation was obtained, with the atomic ratio N/C (Fig. 4a).

Generally, the actual N/C atomic ratio represents the results of changes in the initial composition of precursor matter by diagenetic and maturation processes. Absence of correlation of the N/C ratio with other parameters, besides parameters which are involved by component $\mathrm{C} 3$, points to their genetic connection.

The last two components $\mathrm{C} 3$ and $\mathrm{C} 4$ are made of parameters with significantly lower share of variables. Component $3(15.40 \%$ of variance) is made of complementary $n$ - and iso-alkane parameters: $P h y / n-C_{18}$ ratio and middle/long-chain $n$-alkanes calculated according to Bechtel et al., 2001.

In the investigated coal samples a homologous series of $n$ -alkanes was determined in the range $n-\mathrm{C}_{21}-\mathrm{C}_{33}$ with slight domination of the members with odd number of $\mathrm{C}$ atom, and the ratio of middle/long-chain $\boldsymbol{n}$-alkanes is higher than 1, except with the 598, 12/98 and 4/99 (Table 1). Absence of statistically significant correlations of this alkane ratio, except for the negative correlation trend with isoprenoid phytane and the statistical meaning of positive correlation with atomic ratio $\mathrm{O} / \mathrm{C}$ shows that oxido-reduction conditions have been critically influenced on the distribution of $n$-alkane and isoprenoid phytane (Fig. 4). The $\mathrm{O} / \mathrm{C}$ ratio expressing reduction, i.e. oxidation degree of coal organic matter, which is a result of diagenetic and/or maturation processes, points to the fact that the oxidoreduction conditions and/or specific diagenesis which took place in a relatively closed system of the Krepoljin coal basin had a crucial effect on the distribution of $n$-alkanes and isoprenoid alkane, phytane (Fig. $4 \mathrm{c}$ and d). Phytanic acid, as well as wax ester, their hydrolyzed products, free alcohols and fatty acids are partially degraded during the diagenesis, so that the reduction conditions are partial to the degradation of phytyl side chain of chlorophyll, obtained negative correlation trend with the atomic ratio $\mathrm{O} / \mathrm{C}$ (Fig. 4d).

Component 4 (12.98\% of variance) makes atomic ratios $\mathrm{H} / \mathrm{C}$ and the sterane/hopane ratio (Fig. 4e). The atomic H/C ratio expresses structural characteristics of organic substance as a result of diagenetic and maturation processes. Its separation from the other atomic ratios and the absence of significant statistical correlations with diagenetic parameters, besides the weakly marked positive trend with phytane $/ n-\mathrm{C}_{18} \quad(r=0.364 ; p=0.380 ; n=8)$ demonstrate that the $\mathrm{H} / \mathrm{C}$ ratio of coal represents the results of specific diagenetic parameters connected to the bacterial population, being that one of the possible phytol sources is the share of methanogenic bacteria (Fu et al., 1986). On the other hand, the sterane/hopane ratio is a clear indicator of a lake/terrestrial environment for formation of coals (Isaken, 1991) and of an important role of hopanes participation during the formation of sediments of the Krepoljin basin.

\section{Conclusions}

PCA is used to maximize diagnostic information carried on molecular characteristics significance of biomarker signature of the saturated hydrocarbon fraction of eight coal samples from the Krepoljin brown coal basin of Miocene age.

(1) The most significant, i.e. most "loadings" values of component $\mathrm{Cl}$ are the plant types, such as precursors or participants in early diagenetic transformations and the parameters which describe the degree of diagenetic and thermal transformations of precursor biomass, and they were based on reactions: (a) shifting of methyl group in presence of inorganic sediment constituents, steranerearranged steranes, diasteranes; (b) isomerization in the ring system $\alpha \alpha \alpha \rightarrow \beta \beta \beta \quad C_{29}$ sterane and triterpanes $\beta \alpha \mathrm{Mo} \rightarrow \alpha \beta \mathrm{Ho}$, and (c) isomerization in chiral center of the side chain sequence $R \rightarrow S C_{29}$ steranes $S /(S+R)$.

Main precursors, or participants in early diagenetic transformations are represented by: steranes $\left(\mathrm{Cs}_{27}\right.$-algal biomass, $\mathrm{Cs}_{28}$-moulds, $\mathrm{Cs}_{29}$-high land and water plants), diterpanes (resinous type of higher plants, gymnosperms); then triterpanes of $\alpha$ - or $\beta$-amirin type (dicotyledonous angiosperms) and bacterial population represented by the molecular moieties of hopanes.

(2) Thermal alteration processes of organic matter are strongly influenced by the inorganic sediment constituents. Inhibitory effect of pyrite sulfur makes an impression on transformation reactions of sterane, but not of triterpane.

(3) Due to insufficient selectivity, and even unusability 
of certain maturation parameters of saturated hydrocarbons, but considering great possibilities of the principal component analysis, as well as statistical methods, proof for justification of its use can be found by introducing a new parameter: the ratio of $\alpha$-Phyllocladane/ $\mathrm{Cs}_{27}$ sterane as a reliable source marker of specific plant groups. Non-appearance of statistically important correlations before all with maturation dependent parameters, and after all also with source indicators contributes to the affirmation of the newly-suggested parameter $\alpha$-Phyllocladane/Cs 27 sterane as the real source biomarker of coal.

(4) Molecular markers derived from the distribution and abundance of acyclic alkanes are less significant in the hierarchy of parameters. Higher contents of isoprenoid alkane, phytane, and lower CPI values as well as lower $n$ alkane maximum are most likely the result of participation of hydrocarbons of different origins (higher land plants/ bacterial metabolits), and/or specific diagenesis which occurred in a relatively closed system of the Krepoljin coal basin.

\section{Acknowledgments}

We thank Dr. Hermann Wehner (Federal Institute of Geosciences and Natural Resources, Hannover, Germany) for his help with the GC-MS analysis. This work was supported in part by the Research Fund of the Republic of Serbia.

Manuscript received Nov. 17, 2006 accepted March 28, 2008 edited by Zhang Xinyuan

\section{References}

Bechtel, A., Gruber, R.F., Saschenhofer, Gratzer, R., and Puittmann, W., 2001. Organic geochemical and stable carbon isotopic investigations of coals formed in low-lying and raised mires within the Estern Alps (Austria). Org. Geochem., 32: 1289-1310.

Bechtel, A., Gruber, R.F., Saschenhofer, Gratzer, R., and Puittmann, W., 2003. Depositional environment of the Late Miocene Hausruck lignite (Alpine Foreland Basin): insights from petrography, organic geochemistry, and stable carbon isotopes. Int. J. Coal Geol., 53: 153-180.

Bechtel, A., Saschenhofer, R.F., Kolcon, I., Gratzer, R., Otto, A., and Püttmann, W., 2002. Organic geochemistry of the Lower Miocene Oberdorf lignite (Styrian Basin, Austria): Its relation to petrography, palynology, and the paleoenvironment. Int. $J$. Coal Geol., 51: 31-57.

Bechtel, A., Saschenhofer, R.F., Zdravkov, A., Kolcon, I., Gratzer, R., Otto, A., and Püttmann, W., 2005. Influence of floral assemblage, facies and diagenesis on petrography and organic geochemistry of the Eocene Bourgas coal and the Miocene Maritza-East lignite (Bulgaria). Org. Geochem., 36:
$1498-1522$.

Brukner-Wein, A., and Sajgo, C., 1991. Diagenesis in neogene coal sequence. A study on soluble organic matter. Org. Geochem., 16: 219-227.

Dahl, J., Moldowan, M., and Sundararaman, P., 1993. Relationships of biomarker distribution to depositional environment: Phosphoria Formation, Montana, U.S.A. Org. Geochem., 20: 1001-1017.

Dehmer, J., 1989. Petrographic and organic geochemical investigation of the Oberpfalz brown coal deposit, West Germany. Int. J. Coal Geol., 11: 273-290.

Dehmer, J., 1995. Petrological and Organic Geochemical Investigation of recent peats with known environments of deposition. Int. J. Coal Geol., 28: 111-138.

Dehmer, J., 1988. Petrographische und organisch-geochemische Untersuchungen an rezanten Torfen und tertiären Braunkohlen-Ein Beitrag zur Fazies und Genese gabändeter Braunkohlen. Ph. D. Dissertation, RWTH Aachen, Germany, citate Otto et al., 1997.

Devic, G., Pfendt, P., and Jovancicevic, B., 2006. Pyrite formation in organic-rich clay, calcitic and coal-forming environments. Acta Geologica Sinica (English edition), 80(4): 801-815.

Devic, G., and Pfendt, P. Diagenetic relationships between sulphur species and formation of pyrite in coals and sediments of the Krepoljin basin (Serbia). Energy Sources (in press).

Disnar, J.R., and Harouna, M., 1994. Biological origin of tetracyclic diterpanes, $\boldsymbol{n}$-alkanes and other biomarkers found in lower carboniferous Gondwana coals (Niger). Org. Geochem., 21: 143-152.

Erdtman, H., and Norin, T., 1966. The chemistry of the order Cupressales. Fortschritte der Chemie Organischer Naturstoffe (General Review written in English), 24: 206-287.

Fu Jiamo., Sheng, G., Peng, P., Brassell, S.C., Eglinton, G., and Jiang, J., 1986. Peculiarities of salt lake sediments as potential source rocks in China. Org. Geochem., 10: 119-126.

Gruber, W., and Sachsenhofer, R.F., 2001. Coal deposition in the Noric Depresion (Eastern Alps): Raised and low-lying mires in Miocene pull-apart basins. Int. J. Coal Geol., 48: 89-114.

Hetényi, M., Brukner-Wein, A., Sajgo, Cs., Haas, J., HámorVodó, M., Szantó, Zs., and Tóth, M., 2002. Variations in organic geochemistry and lithology of a carbonate sequence deposited in a backplatform basin (Triassic, Hungary). Org. Geochem., 33: 1571-1591.

Isaken, G.H., 1991. Molecular indicators of lacustrine freshwater depositional environments. In: Eckardt, C.B., Maxwell, S.R., Larter, S.R., and Manning, D.A.C. (eds.), Advances in Organic Geochemistry Advances and Applications in the Natural Environment, 361.

Jørgensen, E., Meye, T., and Sydnes, L.K., 1990. Alkylsubstituted cis-bicyclo[3.3.0]octanes, potentially informative crude oil constituents. Org. Geochem., 15: 1039-1050.

Jovancicevic, B., Vucelic, D., Saban, M., Wehner, H., and Vitorovic, D., 1993. Investigation of the catalytic effects of indigenous minerals in the pyrolysis of Aleksinac oil shale substrates: Steranes, triterpanes and triaromatic steroids in the pyrolysates, Org. Geochem., 20: 69-78.

Kalkreuth, W., Keuser, C., Fowler, M., Mcintyre, M.L.D., Pittmann, W., and Richardson, R., 1998. The petrology, organic geochemistry and palynology of Tertiary age Eureka Sound Group coals, Arctic Canada. Org. Geochem., 29: 799809. 
Kaplunovsky, A., 2004. Factor analysis in environmental studies. J Sci. Eng., 2: 2-22.

Karrer, W., 1958. Konstitution und Vorkommen der organischen Pflanzenstoffe (exclusive Alkaloide). Basel: Birkhäuser, 1207 (in German).

Karrer, W., Cherbuliez, E., and Eugster, C.H., 1977. Konstitution und Vorkommen der organischen Pflanzenstoffe (exclusive Alkaloide). Ergänzungsband 1. Basel: Birkhäuser, 1038 (in German).

Kumar, A.V., Patil, R.S., and Nambi, K.S.V., 2001. Source apportionment of suspended particulate matter at two traffic junctions in Mumbai, India. Atmos., 35: 4245-4251.

Maksimović, B., and Bokčć, P., 1975. The Krepoljin Basin. In: Maksimović, B. and Bokčic, P. (eds.), The Geology of Serbia. The Caustobiolites. Vol. VII. University of Belgrade, 67-72.

Moldowan, J.M., Sundararaman, P., Salvatori, T., Alajbeg, A., Gjukic, B., Lee, C.Y., and Demaison, G.J., 1992. Source correlation and maturity assessment of select oils and rocks from the Central Adriatic Basin. In: Moldowan, J.M., Albrecht, P., and Philp, R.P. (eds.), Biological Markers in Sediments and Petroleum. Englewood Cliffs: Prentice Hall, 370-401.

Noble, R.A., Alexander, R., Kagi, R.I., and Knox, J., 1985. Tetracyclic diterpenoid hydrocarbons in some Australian coals, sediments and crude oils. Geochim. Cosmochim. Acta, 49: 2141-2147.

Noble, R.A., Alexander, R., Kagi, R.I., and Knox, J., 1986. Identification of some diterpenoid hydrocarbons in petroleum. Org. Geochem., 10: 825-829.

Oritz, J.E., Torres, T., Delgado, R.J., Lucini, M., Llamas, F.J., Reyes, E., Soler, V., and Valle, M., 2004. The palaeoenvironmental and palaeohydrological evolution of Padul Peat Bog (Granada, Spain) over one million years, from elemental, isotopic and molecular organic geochemical proxies. Org. Geochem., 35: 1243-1260.

Papanicolaou, C., Dehmer, J., and Fowler, M., 2000. Petrological and organic geochemical characteristics of coal samples from Florida, Lava, Moschopotamos and Kalavryta coal fields, Greece. Int. J. Coal Geol., 44: 267-292.

Peters, K.E., and Moldowan, J.M., 1993. The Biomarker Guide: Interpreting Molecular Fossils in Petroleum and Ancient Sediments. Englewood Cliffs: Pretience Hall, 222.

Philp, R.P., 1985. Fossil Fuel Biomarkers: Applications and Spectra. Amsterdam: Elsevier, 1-79.

Ramanampisoa, L., Radke, M., Schaefer, R.G., Littk, R., Rullkötter, J., and Horsfield, B., 1990. Organic-geochemical characterisation of sediments from the Sakoa coalfield, Madagascar. Org. Geochem., 16: 235-246.

Rullkötter, J., Aizenshtat, Z., and Spiro, B., 1984. Biological markers in bitumens and pyrolyzates of Upper Cretaceous bituminous chalks from the Ghareb Formation (Israel). Geochim. Cosmochim. Acta, 48: 151-157.

Rullkötter, J., Peakman, T., and ten Haven, L.H., 1994. Early diagenesis of terigenous triterpanoids and its implications for petroleum geochemistry. Org. Geochem., 21: 215-233.

Sajgó, Cs., Hetényi, M., and Kedves, M., 1992. Palynology and organic geochemistry of Tertiary low-rank coals in Hungary-I. Workshop on Pyrolysis in Organic Geochemistry, Abstract Volume, 36- 37.

Sirce, M. A., Peulve, S., Saliot, A., De Leeuw, J.W., and Baas, M., 1994. Molecular characterization of organic fraction of suspended matter in the surface waters and bottom nepheloid layer of the Rhone delta using analytical pyrolysis. Org. Geochem., 21: 11-26.

Stefanova, M., Magnier, C., and Velinova, D., 1995. Biomarker assemblage of some Miocene-aged Bulgarian lignite litho types. Org. Geochem., 23: 1067-1084.

Stefanova, M., Marinova, S.P., and Magnier, C., 1999. Aliphatic biomarkers from Miocene lignites desulphurization. Fuel, 78: 1395-1406.

Stefanova, M., Markova, K, Marinova, S.P, and Simoneit, B.R.T., 2005. Molecular indicators for coal-forming vegetation of the Miocene Chukurovo lignite, Bulgaria. Fuel, 84 (14 - 15): 1830 $-1838$.

Stout, S.A., 1992. Aliphatic and aromatic triterpenoid hydrocarbons in Tertiary angiosperous lignite. Org. Geochem., 18: 51-66.

Sukh, Dev., 1989. Terpenoids. In: Rowe, J.W. (ed.), Natural Products of Woody Plants. Berlin: Spinger, 691-807.

Sun,Y.Z., Wang, B.S., and Lin, M.Y., 1998. Maceral and geochemical characteristics of coal seams 1 and oil shale in fault-controlled Huangxian Basin, China. Org. Geochem., 29: 583-591.

ten Haven, H.L., Peakman, T.M., and Rullkötter, J., 1992. $\Delta_{2-}$ Triterpenes: Early intermediates in the diagenesis of terrigenous triterpenoids. Geochim. Cosmochim. Acta, 56: 1993-2000.

Tuo, J., and Philp, R.P., 2005. Saturated and aromatic diterpenoids in Eocene coals and mudstones from China. Applied Geochem., 20: 367-381.

Tuo, J., Wang, X., Chen, J., and Simoneit, B.R.T., 2003. Aliphatic and diterpenoid hydrocarbons and their individual carbon isotope compositions in coals from the Liaohe Basin, China. Org. Geochem. 34: 1615-1625.

Volkman, J.K., Barrett, S., and Blackburn, S.I., 1999. Eustigmatophyte microalgae are potential sources of $\mathbf{C}_{29}$ sterols, $\mathrm{C}_{22}-\mathrm{C}_{28} n$-alcohols and $\mathrm{C}_{28}-\mathrm{C}_{32}$ n-alkyl diols in freshwater environments. Org. Geochem., 30: 307-318.

Volkman, J.K., 1988. Biological marker compounds as indicator of the depositional environments of petroleum source rocks. In: Fleet, J.A., Kelts, K., and Talbot, M.R. (eds.), Lacustrine Petroleum Source Rocks. Geological Society Special Publication, 40: London: Blackwell, 103-122.

Wang, T.G., and Simoneit, B.R.T., 1990. Organic geochemistry and coal petrology of Tertiary brown coal in the Zhouju mine, Baite Basin, South China. Biomarker assemblage and significance. Fuel, 69: 12-20. 